RAVE L 



\section{ROGER NICHOLS}

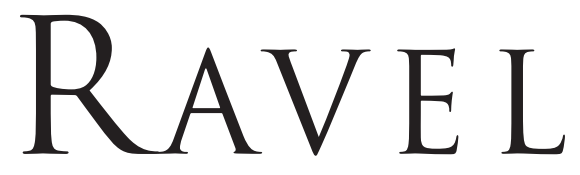




\section{Copyright (C) 2011 by Roger Nichols}

The author and publishers have made every effort to trace the owners of copyright material reproduced in this book. In the event of any omission, please contact the publishers, who will make any appropriate correction in future editions.

All rights reserved. This book may not be reproduced in whole or in part, in any form (beyond that copying permitted by Sections 107 and 108 of the U.S, Copyright Law and except by reviewers for the public press), without written permission from the publishers.

For information about this and other Yale University Press publications please contact: U.S. Office: sales.press@yale.edu yalebooks.com

Europe Office: sales@yaleup.co.uk www.yalebooks.co.uk

Set in Minion Pro by IDSUK (DataConnection) Ltd

Printed in Great Britain by TJ International Ltd, Padstow, Cornwall

Library of Congress Cataloging-in-Publication Data

Nichols, Roger.

Ravel / Roger Nichols.

p. cm.

Includes bibliographical references and index.

ISBN 978-0-300-10882-8 (alk. paper)

1. Ravel, Maurice, 1875-1937. 2. Composers-France-Biography. I. Title.

ML410.R23N52 2011

$780.92-\mathrm{dc} 22$

[B]

A catalogue record for this book is available from the British Library.

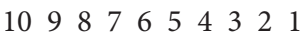


for Sarah, with all my love;

and in affectionate memory of Nigel Fortune, kindest and wisest of friends 
